770 students who are in prison in Turkey, most arrested for protesting against government policies, including the introduction of university fees.

"Freedom of expression in academia is being increasingly clamped down on in Turkey," says Vincent Duclert, a historian at the School for Advanced Studies in the Social Sciences in Paris and a founder of the network. "The GIT initiative will keep the cases in the eye of the international public, and this may bring pressure on Turkish authorities."

Uçarlar, whose PhD thesis on Kurdish language rights was derecognized by Marmara University in 2008, launched GIT's node in Turkey last December. Since then, six further branches have been established in North America and Europe.

GIT Turkey issued a report last week listing a selection of cases of academic rights violations, from arrests on terrorist charges to dismissals for trade-union membership and prosecution for statements deemed harmful to industry. "We don't really know how many cases are out there, because university staff are afraid to speak out," says Uçarlar. "But now we have a platform, people are starting to contact us about their experiences." The group has sent its report to the European Parliament, and has asked that the European Union's annual report on Turkey's bid for membership rates the country on freedom of expression for academics.

Erol Gelenbe, a computer scientist at Imperial College London who was educated in Turkey, points out that although the erosion of academic freedom in the country has accelerated in the past two years, "there has always been little tolerance for independent thinking". He says that at different times over the past few decades, "academics have been expelled from universities either because they were to the right or because they were to the left of the particular government".

Uçarlar agrees that the political situation is "complicated", with right-wingers, left-wingers and staunch secularists all under attack. "I never agreed with the policies of Kemal Gürüz," she says, referring to a former president of the Turkish higher-education council who enforced a ban on wearing the Islamic headscarf in Turkish universities. "But I'm appalled he was arrested on 25 June without credible charges."

Ayşe Erzan, a GIT supporter and a physicist at the Istanbul Technical University who co-founded an alternative science academy when the Turkish Academy of Sciences was put under government management last year, says that "people are getting nervous and there is a feeling we need to resist further slide into undemocratic measures".

\section{Britain names next chief science adviser}

\section{BY EWEN CALLAWAY}

$\mathrm{B}$ iomedical research may soon enjoy an even higher profile in Britain's sciencepolicy agenda. Mark Walport, director of the Wellcome Trust in London, will become the next government chief scientific adviser (GCSA), it was announced last week. He will replace population biologist John Beddington from April 2013.

Walport, a 59-year-old immunologist who took the helm at Wellcome in 2003, will be the first biomedical scientist in 30 years to occupy the role, providing advice directly to Prime Minister David Cameron and the Cabinet. As the outgoing head of one of the world's wealthiest biomedical-research charities, commanding an annual budget of more than $£ 600$ million (US\$940 million), he will be one of the most influential scientists to hold the position.

"I think it's going to be really important in terms of assuring that biomedical science is very high on the agenda in the government," says Nic Jones, chief scientist at the Londonbased charity Cancer Research UK. Although the GCSA does not oversee the research councils that dole out most government science funding, Jones hopes that Walport will make a strong case for biomedical and translational research in the government's next spending review, expected in the next two years.

The UK coalition government has already shown favour for biomedicine over other sciences. It largely protected the Medical Research Council's $£ 800$-million research budget in the latest spending review, and a December 2011 life-sciences strategy which Walport helped to develop - emphasizes translational-research initiatives such as drug repurposing and stem-cell therapies. But Walport will need to be an advocate for science policy-making throughout government, says James Wilsdon, a science-policy expert at the University of Sussex in Brighton, UK. "The key thing will be that he moves above and beyond issues and areas where he's already been associated, to act as a broader leader across the community, across a broader set of issues."

Wilsdon and others expect that, just as Beddington championed government policies to address global food security and climate change, Walport will push his own favoured issues, such

as open access to research literature and data. Last week, the Wellcome Trust announced that it may withhold funding to grant recipients who do not make their research available within six months of publication - a policy instituted under Walport's watch. Open access is already gaining traction in the UK government (see Nature 486, 302-303; 2012), and with Walport beating the same drum, "that creates a real opportunity for more rapid and far-reaching progress to embed these sorts of changes in the research community," says Wilsdon.

One of the key tests for a GCSA is how they deal with crises outside their areas of expertise, says Colin Blakemore, a neuroscientist at the University of Oxford, UK, and former chief executive of the Medical Research Council. Beddington, for example, was confronted with

"The key thing will be that he moves above and beyondissues and areas where he's already been associated." access to expertise to confront such challenges. At the Wellcome Trust, he showed his mettle by pushing through a controversial change to funding policy, targeting more cash to outstanding scientists rather than to individual research projects. He also boosted the trust's commitment to public engagement, the arts and the humanities.

Walport's appointment has unleashed speculation about who will replace him as head of the Wellcome Trust. Insiders say that the hunt for a successor will consider scientists with backgrounds in either academia or industry, and will be explicitly international. "I would expect a global search, a big-hitting shortlist," says Wilsdon. "It is now one of the biggest jobs in international science." - SEE EDITORIALP.5

\section{CORRECTION}

The News story 'Fetal tests spur legal battle' (Nature 486, 454; 2012) located medicalgenomics company Natera in Redwood City, California. The firm has actually relocated to San Carlos, California. 